\title{
COMMENTS
}

\section{PRIVATE RIGHTS OF ACTION UNDER THE INVESTMENT COMPANY ACT}

A PROBLEM of major importance in securities regulation has recently come before the federal courts as a large number of plaintiffs assert the existence of private rights of action under the Investment Company Act of I940.1 Since the statute itself is generally silent as to private rights of action, these plaintiffs contend that private actions can be supported by implication.

The Investment Company Act closely regulates the relations between the investment company and its officers, directors, underwriters, and investment advisers. In a number of cases now pending, directors and investment advisers of mutual funds are charged with abuse of their fiduciary positions and with mismanagement and waste of the funds' assets on account of the payment of allegedly excessive investment advisory fees. ${ }^{2}$ Some of the substantive issues in these cases could prob-

\footnotetext{
${ }^{2} 54$ Stat. 789 (1940), as amended, I5 U.S.C. $\$ \S 80 a-1-80 a-52$ (I958).

${ }^{2}$ Most funds pay an advisory fee of $I / 2$ of $\mathrm{I} \%$ of the fund's net assets each year, although a few funds have sliding scales for compensation of the investment advisor, with decreasing percentages applied to successive increments of the fund. See Mutual Funds Fight Holder Suits Charging Excessive Fees to Management Concerns, The Wall Street Journal, Nov. 3, 1960, p. 28, cols. 2-3. There seems to emerge a general pattern of allegations in complaints in these excessive advisory fee cases, all employed to show that the advisory fee is unreasonable and set collusively in the interest of the adviser and not the fund. They may be briefly listed as follows:

I. Directors of the adviser who are also directors of the fund dominate and control the fund so that these affliated directors are able to fix the advisory fee in the interest of the adviser and not the fund.

2. The advisory fee charged bears no relation to the reasonable value of the services rendered. Other funds gets the same advice for less.

3. The flat $I / 2$ of I\% fee, even if scaled down after $\$ 100$ or $\$ 200$ million, is unreasonable per se in that the cost of investment management does not increase in proportion to the increase in a fund's net asset value.

4. Where a series of funds is involved the adviser exacts the same $1 / 2$ of $1 \%$ from each fund despite the fact that his costs are significantly lower due to the great duplication of securities contained in the portfolios of these funds.

5. Fund directors have sought to increase the fund's net asset value by merger, acquisition, or aggressive sales techniques even though such growth would harm the fund. The
} 
ably be raised under state statutes or common law. But the problems which these cases present can receive a more uniform solution if they are treated as problems of federal law under the Investment Company Act. This Act offers appropriate standards for gaging fiduciary conduct and the federal judiciary has had considerable experience in applying such standards to securities regulation. ${ }^{3}$ The present question then is a procedural one: may these plaintiffs come into federal court other than by diversity jurisdiction? This question was squarely presented to the Eighth Circuit Court of Appeals in the case of Brouk v. Managed Funds, Inc. ${ }^{4}$

\section{Brouk v. Managed Funds}

Managed Funds, Incoroprated, is an open end investment company registered under the Investment Company Act, having net assets

reason for such policies is the great benefit which will accrue to the investment adviser whose fee is tied to the fund's net asset value.

6. Though a mauagement has produced poor results, the advisory contract is nevertheless consistently renewed, a demonstration of the failure of the fund's board to seek the best advice at the lowest price, all of which is due to the domination and interests of the directors affiliated with both the investment adviser and the fund.

7. In many cases the directors of the fund have appropriated the investment advice to their own use or allowed that information to be used in the management of other portfolios.

Thus, in an "excessive fee" suit the plaintiff's case turns on the allegation that the fees paid by the fund to its investment adviser, pursuant to their investment advisory contract, are unreasonable and excessive and constitute an illegal waste of the fund's assets.

The first of the "excessive fee" suits to be decided on the merits upheld the schedule of fees paid by Chemical Fund to its manager and distributor, F. Eberstadt \& Co. The Chancery Court of Delaware dismissed the complaint, observing that plaintiffs had not proved the advisory fees to be excessive. This decision, however, does not necessarily indicate the probable decision of other suits pending, because Chemical Fund is among the small number of mutual funds having sliding fee scales. Eberstadt receives $1 / 2$ of $1 \%$ on the first $\$ 75$ million of the fund's assets, $3 / 8$ of $1 \%$ on the following $\$ 50$ million, and $1 / 4$ of $1 \%$ on all additional assets. In 1960 , Eberstadt received $\$ 894,191$ in management fees, Chemical Fund having about $\$ 302$ million in assets.

Under pressure of a stockholder's suit, Lazard Fund recently reduced the fee of its adviser, Lazard Freres \& Company, on assets in excess of $\$ 100$ million. Another fund which has recently switched to the sliding scale fee basis is State Street Investment Corp.

See Fund Wins Skirmish Over Management Fees, Business Week (May 13, 1961) p. 117 ; U.S. News \& World Report (March 13, I961) p. 112.

$\rightarrow{ }^{8}$ Another important advantage gained by bringing these cases under the Investment Company Act is the availability of nationwide service of process under $\S 43$ of the act. 4286 F.2d 901 (8th Cir. 196I), cert. granted, 29 U.S.L. WEEK 3378 (U.S. June 19, 1961) (No. 947). 
of about seventy million dollars. ${ }^{5}$ In July of 1959 , the Securities and Exchange Commission issued a stop order against Managed Funds, ${ }^{6}$ under section 8(d) of the Securities Act of 1933. This order prevented further sale of shares in the Fund and, indirectly, precipitated the ouster of the directors, officers, and affliated persons who formerly controlled Managed Funds. Subsequently, civil actions were brought to recover damages from this former controlling group and to enjoin the perpetration of certain practices they had instituted.

Emanuel Josephson brought a stockholder's derivative action on behalf of Managed Funds, Inc., in the United States District Court in Delaware, and Managed Funds itself brought a direct action in the Eastern District of Missouri. Josephson's suit was transferred to Missouri and consolidated with the Managed Funds case. ${ }^{7}$ Allegations in the two complaints were based principally on the findings of the SEC in the stop order proceeding. Several persons were implicated in that investigation. Hilton and Hovey Slayton (referred to as the individual Slaytons) were the principal officers and dominant directors of Managed Funds, Inc. The individual Slaytons owned or controlled: (I) Slayton Associates, which had an investment advisory contract with Managed Funds, Inc., (2) Slayton \& Co., which sold Managed Funds shares to the public through its own sales organization, and (3) Mutual Funds Distributors, Inc., which distributed Managed Funds shares through brokers and dealers. Stephen Jaquith, a member of the stock brokerage firm of Model, Roland \& Stone, was retained by Slayton Associates under a contract which was found by the SEC to delegate the investment advisory function to him. ${ }^{8}$ Jaquith's compensation under this contract consisted of brokerage commissions on the securities transactions of Managed Funds. The Commission found that Jaquith was required to share these commissions with two individuals close to the Slaytons, a relative and a former business associate. Over a five

\footnotetext{
- This was the approximate size of the company at the end of 1958 .

'In the matter of Managed Funds, Inc., Securities Act Release No. 4122, CCH FED. SEC. L. REP. I 76,662 (July 30, 1959).

'An additional party plaintiff is Protective Casualty Insurance Company, which was allowed to intervene and adopt the Josephson complaint. There are thirty parties defendant in the consolidated case, including the investment adviser, the underwriting companies, various officers and directors of these companies and of Managed Funds, and a stock brokerage firm.

${ }^{8}$ Jaquith's contract purported to delegate to him greater powers over the Managed Funds portfolio than was given to Slayton Associates by its contract with Managed Funds.
} 
year period, about two million dollars in brokerage commissions were directed to Model, Roland \& Stone on account of Jaquith and the parties who shared these commissions with him. During that same period, Slayton Associates, Inc., received over one million dollars for investment advisory services, and the individual Slaytons received large salaries from Managed Funds.

The Commission found that the board of directors of Managed Funds "gave scant attention to the management of the registrant; made no efforts to be informed concerning registrant's policies and whether such policies were being followed; made no decisions concerning purchases and sales of portfolio securities [although the contrary was represented in the prospectus]; and generally permitted the registrant to be managed by the Slaytons without consultation with or approval by the board as a whole. ${ }^{39}$ The Commission further found that Jaquith was an investment adviser under section I 5 of the Investment Company Act and that his contract had never been approved by the shareholders or directors of Managed Funds, as the Act requires; ${ }^{10}$ that brokerage commissions on the securities transactions of Managed Funds were directed to Jaquith in payment for advisory services which Slayton Associates was obligated to perform and for which it was paid; that such brokerage commissions were also directed to a relative and to a former business associate of the Slaytons; that brokerage commissions were directed to the broker-dealers who sold Managed Funds shares, under a reciprocal business arrangement on which the prospectus was silent. The Commission also found that, although Managed Funds represented its primary objective as capital growth, the company followed instead a policy of providing high and uniform quarterly dividends in order to promote sales of its shares and so increase sales commissions and management fees received by the Slayton companies, and in order to gain the nine per cent sales load ${ }^{11}$ on reinvestments of the distributed moneys (since many shareholders did reinvest customarily); that portfolio management was much impaired by this dividend policy; that securities frequently had to be sold to generate

\footnotetext{
${ }^{\circ}$ CCH FED. SEC. L. REP. I 76,662 at p. 80,509.

${ }^{20}$ Jaquith's contract violated the standards of $\S 15$ of the act for an advisory contract in that it did not give a satisfactory description of his total compensation: the contract specified only the minimum level of compensation and said nothing about the maximum.

${ }^{11}$ The sales load is the mark-up over net asset value. The fund itself receives net asset value for its shares, while the broker, distributor, and/or underwriter receive the sales load.
} 
capital gains for distributions already authorized by the board of directors; that many poor investments were retained merely to avoid realization of capital losses, which would affect the distributable capital gains; that securities were sometimes bought back at higher prices after they had been sold to realize a distributable gain; that portfolio turnover was extremely and uncommonly high for an investment company, the turnover generating desired brokerage commissions for Jaquith and his associates. ${ }^{12}$

These findings of the Commission were generally adopted and alleged as facts in both the Josephson and Managed Funds complaints. ${ }^{13}$

${ }^{13}$ Findings of the Commission are set forth in detail in In the matter of Managed Funds, Inc., Securities Act Release No. 4122, CCH FED. SEC. REP. I 76,662 (July 30, 1959).

${ }_{18}$ The principal allegations in these complaints are as follows, quoting and paraphrasing from the Brouk opinion, 286 F.2d at 903-04:

Managed Funds' Complaint

Count I: Alleges the facts set forth in the SEC's stop order opinion; further avers that the defendants committed violations of the Investment Company Act by:

(a) operating the Fund in the interest of directors, etc.; rather than the Fund's security holders,

(b) causing the Fund to publish and circulate documents containing untrue statements or omitting material facts,

(c) causing the Fund to deviate from a fundamental investment policy.

Count one further alleges that defendants Model, Roland \& Stone and Jacquith acted as investment advisers without a written contract approved by the outstanding voting securities of the Fund.

Count 2: Avers that the Fund inay be liable to purchasers of its shares by reason of the defendants' having caused the Fund to file a false registration statement under the Securities Act of 1933; that the Fund's name and good will were damaged and that the Fund incurred counsel fees and other expenses in connection with stop order proceedings before the Securities and Exchange Commission.

Count 3: Avers that the individual Slaytons, as President and Vice-President of Managed Funds, occupied a fiduciary relationship with the Fund; that Model, Roland \& Stone and Jacquith acted as investment advisers and therefore occupied a fiduciary relationship; that all the other defendants had knowledge, actual or constructive, of these fiduciary relationships; that Slaytons and Model, Roland \& Stone committed waste and mismanaged the Fund, and that all except the outside directors profited thereby; that all other defendants, by reason of their alleged knowledge of the fiduciary relationships of the Slaytons and Model, Roland \& Stone are liable for their acts.

Count 4 : Avers a conspiracy among defendants.

Each of the counts prays for money damages and an accounting for profits from each of the defendants.

The Josephson complaint recites the same basic facts as Count I of the Fund's amended complaint, and avers also that "the wrongful acts herein described have been and continue to be committed by the defendants against Managed Funds in breach of legal and fiduciary obligations that are inherent by reason of the relationship of the parties." Id. at 904. Josephson prays for an injunction in addition to an accounting and damages. 
In addition, the complaints alleged that: "The defendants committed, or with actual or constructive knowledge as herein above set forth, aided, abetted, acquiesced in or condoned, directly or indirectly, violations of the Investment Company Act of 1940.\$14

Certain of the defendants, outside directors who were in effect "dummy" directors, moved to dismiss the complaints as to them for lack of jurisdiction of the subject matter. ${ }^{15}$ The district court denied these motions, but determined that they presented " $a$ controlling question of law upon which there is a substantial ground for difference of opinion, ${ }^{316}$ whereupon immediate appeal to the Court of Appeals for the Eighth Circuit was allowed. ${ }^{17}$ The Court of Appeals reversed. In holding that the complaint did not support the federal jurisdiction, the court noted: ${ }^{18}$

At common law directors are liable to exercise due care and are not insurers. . . . The complaints here substantially seek to hold these former directors to strict liability as insurers. The Act they rely on not only contains no such provision but plainly negates any intent to create such an innovation. The reliance upon implication to support the jurisdiction is not justified in the face of the legislative intent to exclude it.

A petition for rehearing, in support of which the SEC filed a brief amicus, was denied. ${ }^{19}$

\section{Brown v. Bullock}

About two months after the Eighth Circuit decided Brouk, the United States District Court for the Southern District of New York ruled differently in a similar procedural situation presented by Brown $v$. Bullock. ${ }^{20}$ Again, the problem of construing the Investment Company Act with regard to private rights of action was raised by a motion to dismiss the complaint.

The mutual fund involved, Dividend Shares, Incorporated, is a

\footnotetext{
${ }^{14}$ Paragraph 2I, count $\mathrm{x}$, Managed Funds' amended complaint, as quoted by the court at $286 \mathrm{~F} .2 \mathrm{~d} 901,903$.

${ }^{15}$ Also, two defendants sought dismissal for lack of jurisdiction of their persons. They had been served with process in another state, presumably under the provision of the Investment Company Act allowing nationwide service of process, 54 Stat. 844 (1940), 15 U.S.C. \& 80a-43 (1958).

${ }^{10} 286$ F.2d at 902 .

${ }^{17}$ This appeal was allowed under 28 U.S.C. $\S$ r292(b) (1958).

${ }^{18} 286$ F.2d at 918.

${ }^{10}$ Rehearing denied on March 6, 1961. The Supreme Court has granted certiorari. See note 4 supra.

${ }^{20}$ CCH FED. SEC. L. REP. 191,013 (S.D.N.Y. March 9, 1961).
} 
diversified open end investment company, registered under the Investment Company Act and having net assets of about 255 million dollars. ${ }^{21}$ Calvin Bullock, Limited, is investment adviser to Dividend Shares and also the chief underwriter and sole distributor of its shares. Plaintiffs, shareholders of Dividend Shares, brought suit "derivatively on behalf of the Fund and representatively on behalf of themselves and all other shareholders of the Fund similarly situated."22 The Fund and its management company, Calvin Bullock, Limited, were named as corporate defendants. The nine individual defendants are directors of the Fund and the Management Company. Among them are Hugh Bullock, president and a director of both the Fund and the Management Company, and Robert Clark, executive vice-president of the Management Company and a director of both the Fund and the Management Company.

Although the complaint stated but one count, the court grouped the allegations as follows: ${ }^{23}$ (I) Complete domination and control of Dividend Shares by the defendant Management Company and defendants Bullock and Clark; (2) wrongful transactions concerning the investment advisory contract and its yearly extensions; and (3) wrongful transactions concerning the underwriting contract and its yearly extensions.

For the five fiscal years preceding 1959 the Management Company received about four million dollars in investment advisory fees and realized some two million dollars on sales of the Fund's shares. The advisory fees were alleged to be not only excessive but also discriminatory in that the Management Company furnished generally similar services to other investment companies for a lesser compensation, both absolutely and proportionately to the size of the investment companies involved. ${ }^{24}$ The complaint further alleged that the making of excessive advisory payments and the receipt thereof by the Management Company constituted an "unlawful and willful" conversion of the Fund's assets by the defendants, as well as gross abuse of trust, gross misconduct, waste and spoliation of the Fund's assets. ${ }^{25}$

\footnotetext{
${ }^{21}$ This was the approximate size of the fund in April, 1960 .

${ }^{22}$ CCH FED. SEC. L. REP. T $91,01_{3}$ at p. 93,355, where the court is quoting from paragraph 2 (b) of the complaint.

${ }^{33}$ CCH FED. SEC. L. REP. T $91_{1} 0_{13}$ at pp. 93,355-59. There is also a group of "procedural" allegations, necessary as a matter of form for derivative and representative actions.

${ }^{24} I d$. at p. 93,357 .

${ }^{25} \mathrm{Ibid}$.
} 
The gravamen of the complaint, therefore, is excessive fees and breaches of fiduciary duty. But there are other allegations: $:^{20}$

that the defendants knew the compensation to be excessive; that the so-called independent directors were beholden to Bullock and Clark for lucrative positions; that they were dominated and controlled by Bullock and Clark; that the Fund's personnel, business, affairs, management and operations were completely dominated and controlled by Bullock, Clark and the Management Company; that the board of directors of the Fund had abdicated their functions in favor of Bullock, Clark, and the Management Company; that the Fund's contracts with the Management Company were the result of collusion between the Fund's directors and the Management Company and designed for the benefit of the fiduciary (the Management Company) to the detriment of the Fund; that the Fund's directors abdicated their statutory duty to use their judgment in approving the annual extensions of the investment advisory and underwriting contracts; that false and misleading proxy statements transmitted by the defendants were used to induce the Fund's stockholders to forego the exercise of their statutory absolute privilege to terminate the investment advisory contract at any time; in brief, that the Fund became a mere adjunct of the Management Company through the defendants' gross misconduct and gross abuse of trust.

Bullock is an opportune case for finding a private right of action under the Investment Company Act because defendants are charged with violation of eight different sections of the act. The Court tabulated them thus: ${ }^{27}$ section $15(a)(3)$, relating to unlawful investment advisory

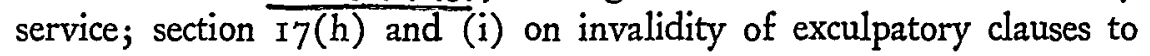
protect officers and directors; section 2O(a) and various SEC rules on proxy solicitation; section 34 (b) on untrue statements in certain documents; section 36 on gross misconduct and gross abuse of trust; section 37 on larceny, embezzlement, and willful conversion; section 44 on jurisdiction of suits at law and in equity; ${ }^{28}$ and section $47(\bar{b})$ on invalidity of contracts violating the act. Defendants could not strictly be

${ }^{20} \mathrm{Id}$. at p. 93,362 . As to the alleged wrongful transactions concerning the investment advisory and underwriting contracts and their extensions, the complaint alleges that "the relative positions of the defendants in such transactions were as follows: Bullock, Clark and the Management Company 'caused' the transactions. The other eight defendants 'participated or acquiesced in' such transactions 'with knowledge or notice of their wrongful character.'" Id. at pp. 93,356,93,358.

${ }^{27} I d$. at pp. 93,359-60.

${ }^{28}$ Although $\S 44$ is central to this case, a close reading of the section does not indicate any sense in which defendants could have violated it. The court was apparently overzealous in its tabulation of alleged offenses. 
said to have violated some of these sections, however, unless the act im-. plicitly establishes fiduciary standards.

The relief sought by the plaintiffs is that the investment advisory and underwriting contracts and their extensions be declared null and void, that the Management Company and individual defendants be required "to repay the investment advisory fees to the Fund" and "to account to the Fund and its shareholders for profits and damages," and that plaintiffs recover the costs and expenses of bringing suit. ${ }^{29}$

Defendants moved to dismiss the complaint for lack of jurisdiction over the subject matter and for failure to state a claim upon which relief can be granted. ${ }^{30}$ Before ruling on defendants' motion, the disstrict court cogently framed the dispositive issues: ${ }^{31}$

I Whether the statutory provisions upon which the plaintiffs' claims is based created any duties owing by the defendants to the Fund or to the plaintiffs.

II Whether the defendants' acts as alleged in the complaint violated any of those duties.

III Whether the plaintiffs can bring this action in this court to enforce the liabihities and duties created by this act.

Its remarks prefatory to deciding further indicate the spirit in which this court approached its task: $:^{32}$

These issues pose a problem of statutory interpretation requiring a view in depth. It is interpretation of the various statutory provisions-not fragmented into isolated sections nor subjected to mere black-letter reasoning-as integrated parts of a remedial enactment possessing a fundamental unity of specific policy and stated objectives.

Although the Brouk decision in the Eighth Circuit was urged upon it, the court expressed its "respectful disagreement with the views expressed ... to the extent that they restrictively interpret the I 940 Act," and denied the motion to dismiss. ${ }^{33}$ In view of the similarity of alleged misconduct by defendants in Brouk and Bullock, the diametrical holdings of the two cases leave some doubt as to the existence and extent of private remedy under the Investment Company Act. ${ }^{34}$

${ }^{30}$ CCH FED. SEC. L. REP. I 9 r,or 3 at p. 93,359.

${ }^{30}$ Motion pursuant to FED. R. Clv. P. I2(b) (r) and (6).

${ }^{81} \mathrm{CCH}$ FED. SEC. L. REP. I 91,013 at p. 93,360.

${ }^{32}$ Ibid.

${ }^{33} I d$. at p. 93,385 . An interlocutory appeal is now pending.

${ }^{34}$ The superficial distinction which the Bullock court makes, at pp. 93,384-85 of CCH FED. SEC. L. REP. T $9 \mathrm{I}_{1} \mathrm{Or}_{3}$, is not at all satisfactory. It relies on some un- 


\section{The Private Right of Action}

Whenever a case arises under the Constitution, laws, or treaties of the United States, jurisdiction is vested in the district courts by the "federal question" statute, ${ }^{35}$ provided the amount in controversy is greater than ten thousand dollars. Although plaintiffs in both Brouk and Bullock contended that a federal question was presented, they relied on the more specific wording of section 44 of the Investment Company Act: ${ }^{36}$

The district courts of the United States shall have jurisdiction of violations of this title or the rules, regulations, or orders thereunder, and concurrently with State and Territorial courts, of all suits in equity and actions at law brought to enforce any liability or duty created by, or to enjoin any violation of, this title or the rules, regulations, or orders thereunder.

This section is quite similar to the jurisdictional clauses in the Securities Act of $1933^{37}$ the Public Utility Holding Company Act of $1935{ }^{38}$ and the Trust Indenture Act of $1939 .^{30}$ Section 27 of the Securities Exchange Act of $x 934$ is identical, except that it vests exclusive jurisdiction in United States courts to enforce liabilities and duties created by the 1934 Act. ${ }^{40}$ The term violations, as used in these statutes, encompasses civil litigation as well as criminal cases. ${ }^{41}$ In Bullock the district court adopted the SEC's interpretation of section 44 , thus: ${ }^{42}$

fortunate language in the Brouk opinion to the effect that directors are not liable as insurers. 286 F.2d at 918 . The Managed Funds complaint charged that "the defendants committed, or with actual or constructive knowledge . . . aided, abetted, acquiesced in or condoned, directly or indirectly, violations of the Investment Company Act of 1940." 286 F.2d at 903. To say that this complaint seeks to hold defendants liable as insurers is merely to restate the Brouk court's conclusion that the act of itself establishes no implicit fiduciary obligations.

${ }_{28}^{35} 8$ U.S.C. $\$ 133$ I (1958).

${ }^{36}{ }_{54}$ Stat. 844 (1940), 15 U.S.C. $\$ 80 a-43$ (1958).

${ }_{47}{ }_{48}$ Stat. 86 ( $\mathrm{x}_{933}$ ), as amended, $x_{5}$ U.S.C. $\$ 77 \mathrm{~V}$ ( 1958 ).

${ }_{48} 49$ Stat. 835 (1935), as amended, 15 U.S.C. \$ 79y (1958).

${ }_{53}{ }_{53}$ Stat. 1175 (1939), 15 U.S.C. $\$ 77 v v v(b)$ (1958).

4048 Stat. 902 (1934), as amended, 15 U.S.C. $\$ 78 a a$ (1958).

${ }^{11}$ Osborne v. Mallory, 86 F. Supp. 869 (S.D.N.Y. 1949); Grossman v. Young, 70 F. Supp. 970 (S.D.N.Y. 1947 ).

${ }^{4}$ CCH FED. SEC. L. REP. If gI,ox3 at P. 93,384. See Memorandum of the Securities and Exchange Commission Amicus Curiae filed with the United States District Court for the Southern District of New York, in the case of Brown v. Bullock, p. 3; Motion of Securities and Exchange Commission for Leave to Participate Amicus Curiac, filed with the United States Court of Appeals for the Eighth Circuit in the case of Brouk v. Managed Funds, p. 4 . 
Since the Commission can bring only equity suits and only in the federal courts [sections 35 (d), 36 and 42 (e)], the other elements in section 44 must refer to appropriate private actions and suits, in the proper federal or state court to enforce any liability created by the Act.

Standing alone section 44 appears to envision private actions. However, inasmuch as the draftsmen of the I940 Act copied this jurisdictional clause from cognate sections of previously enacted federal securities statutes, there may be a surplusage of jurisdictional power in this clause so far as the Investment Company Act alone is concerned. But even in the absence of section 44 , federal jurisdiction for a private action might be sustained by implication.

Once plaintiffs have established a federal claim, then under the principle of pendent jurisdiction the court is also empowered to decide any common law claims involved in their action if the same proof will sustain both the federal and nonfederal claims. ${ }^{43}$ However, the federal claim must be substantial and not " 'a mere excrescence or superfluity tacked onto' a non-federal claim."344

In order to save a civil liability-complaint against dismissal, the plaintiff must do more than justify the federal jurisdiction; he must state a claim on which relief can be granted. ${ }^{45}$ Compliance with this latter requirement is relatively easy when a federal statute expressly provides for the appropriate civil liability. Under the Investment Company Act, however, express civil liability provisions are quite limited in scope and, indeed, are so miniscule that the Brouk court overlooked their existence. ${ }^{46}$ Consequently, plaintiffs in this type of case

${ }^{63}$ Hurn v. Oursler, 289 U.S. 238 (1933); Schwartz v. Eaton, 264 F.2d 195 (2d Cir. r959); Zalkind v. Scheinman, 139 F.2d 895 (2d Cir. 1943).

" CCH FED. SEC. L. REP. If 9 I, $\mathrm{I}_{3}$ at $\mathrm{p} .93,373$, where the court is quoting from Howard v. Furst, 238 F.2d 790, 794 (2d Cir. 1956).

${ }^{45}$ Bell v. Hood, 327 U.S. 678 (1946), discusses the technical difference between lack of jurisdiction over the subject matter and failure to state a claim upon which relief can be granted.

${ }^{60}$ Section $29(f)$ of the act incorporates by reference the civil liability provision in $\S$ I6 of the Securities Exchange Act with regard to recovery of insiders' short-swing trading profits. Section $29(f)$ is, however, applicable only to directors and other affiliates of closed-end investment companies. The SEC contends that $\S 24(\mathrm{e})(3)$ provides for civil liability of directors in connection with registration statements filed under the Securities Act. See Motion of Securities and Exchange Commission for Leave to Participate Amicus Curiae, filed with the United States Court of Appeals for the Eighth Circuit in Brouk v. Managed Funds, pp. 4-5, n. 5. This contention appears to be erroneous upon close reading of the statute. Section $24(\mathrm{e})(3)$ merely provides for certain operative facts relating to a liability which arises under the Securities Act. The Commission further urges that $\S \S \times 7(h)$ and $38(\mathrm{c})$ contemplate civil liability under the 1940 act. This is questionable, however. 
must usually proceed on the theory that the act establishes certain standards of conduct whose breach is civilly actionable by implication.

The Brouk and Bullock decisions evince a fundamental conflict as to whether the Investment Company Act creates fiduciary standards. The Court of Appeals in Brouk recognized that conduct on the part of directors or other affliates of investment companies that violates the act will invoke the criminal and administrative sanctions set forth in the various sections of the act. But the court rejected the notion that these statutory proscriptions embrace a standard of fiduciary care whose breach would be civilly actionable by injured parties. The SEC, on the other hand, has suggested that at least eleven sections of the act codify or expand the common law duties of directors of investment companies. ${ }^{47}$ The district court in Bullock generally adopted plaintiffs' position "that specific sections of the Act impose specific duties upon the directors, investment advisers and principal underwriters of registered companies; and that section 44 grants federal jurisdiction if violations of these specific statutory duties are alleged." ${ }^{48}$ But, in addition to fiduciary duties implied from the "thou shalt not" clauses, the Bullock court also determined that the various grants of power in the act necessarily carry with them "the imposition of corresponding fiduciary obligations. ${ }^{39}$ Whether the act imposes fiduciary duties is

${ }^{17}$ These are $\S 10$, regulating composition of the board of directors; $\S 1_{5}(\mathrm{c})$, nullifying the vote of directors in certain instances; $\$ 17(\mathrm{a})$; prohibiting sales transactions between directors and their investment companies, and also prohibiting loans to directors; $\$ \mathrm{I}_{7}$ (d) prohibiting joint participations by directors with their investment companies; $\$ 17(\mathrm{e})$, restricting directors' actions as agents or brokers for their investment companies; $\S$ I $_{7}(\mathrm{~h})$, banning exculpatory clauses to relieve directors of liability for various sorts of misfeasance including reckless disregard of duties; \& 25 (c), relating to injunctions against certain plans of reorganization; $\$ 32(a)$ (1), disqualifying certain directors to vote in the selection of an accountant; $\S 29(f)$, relating to recovery of short-swing trading profits from directors; $\$ 37$, creating a federal offense in cases of larceny or embezzlement by directors; and $\S_{3} 6$, relating to injunctions against directors guilty of gross misconduct. See Motion of Securities and Exchauge Commission for Leave to Participate Amicus Curiae, filed with the United States Court of Appeals for the Eighth Circuit in Brouk v. Managed Funds, pp. 5-10.

${ }^{18}$ CCH FED. SEC. L. Rep. T 91,013 at p. 93,363.

${ }^{10} I d$. at p. 93,375.

"The grant of these defined powers, as specified by the Act, carries with it the imposition of corresponding duties. The power to extend the investment advisory contract necessarily carries with it the duty to determine whether or not the extension is desirable and in the best interest of the company. The power to terminate the investment advisory contract necessarily carries with it the duty to keep alert for reasons which might make termination necessary or desirable .... The objectives of the Act would be nullified if the directors were free to extend mechanically the contract without 
ultimately a question of congressional intent. However, some courts hold that the existence of private rights of action under a statute is not dependent on any affirmative indications that they were intended: "On the contrary, they are implied unless the legislation evidences a contrary intention. .150

Professor Loss discusses the theoretical bases for implied liability under the federal securities statutes thusly: ${ }^{51}$

honestly exercising their best judgment. The objectives of the Act would be equally frustrated if the directors were free to close their eyes to any developments making the termination of the contract advisable.

By giving the directors the right to extend and to terminate the contract, the Act necessarily also imposes upon the directors the fiduciary duty to use these powers intelligently, diligently and solely for the interests of the company and its stockholders. These specific fiduciary duties are created by the Act. Their violations subjects the directors to liability, which can be enforced in the federal courts under section 44 of the Act." Ibid.

${ }^{80} \mathrm{CCH}$ FED. SEC. L. ReP. If 9 I,013 at p. 93,366. Accord, Taussig v. Wellington Fund, Inc., I87 F. Supp. I79, 217 (D. Del. 1960); Narramore v. Cleveland, C.C. \& St. L. R.R., 96 Fed. 298, 300 (6th Cir. 1899). Contra, Brouk v. Managed Funds, Inc., 286 F.2d 90I, 9 I2 (8th Cir. I96I).

${ }^{51}$ Loss, Securities Regulation 1043-45 (195I). The common-law tort basis of which Loss speaks has been written into the Restatement, as follows:

The violation of a legislative enactment by doing a prohibited act or by failing to do a required act, makes the actor liable for an invasion of an interest of another if:

(a) the intent of the enactment is exclusively or in part to protect an interest of the other as an individual; and

(b) the interest invaded is one which the enactment is intended to protect; and

(c) where the enactment is intended to protect an interest from a particular hazard, the invasion of the interest results from that hazard; and

(d) the violation is a legal cause of the invasion, and the other has not so conducted himself as to disable himself from maintaining an action. REsTATEMENT, TORTS $\$ 286$ (1934).

See generally Morris, The Relation of Criminal Statutes to Tort Liability, 46 HARv. L. Rev. 453 (1933); Lowndes, Civil Liability Created by Criminal Legislation, I6 MINn. L. REv. 361 (1932); Thayer, Public Wrong and Private Action, 27 Harv. L. REV. $3 \mathrm{I}_{7}$ (1914). See also Note, Federal Jurisdiction in Suits for Dannages under Statutes not Affording Such Remedy, 48 Colum. L. REv. 109o (1948). Prosser, TORTS 265 (194I) takes an unenthusiastic view of such implied rights of action: "In the ordinary case . . the obvious conclusion is that the legislature either did not have the civil action in mind at all, or deliberately omitted to provide for it."

Because of the distinction between a cominon law tort action grounded on breach of a federal statute (which is taken as a standard of prudence and care for the purpose of showing negligence), which theoretically requires diversity of citizenship to get into federal court, and an action based on a liability created by the statute itself, there is much discussion in Brouk and other cases as to whether the alleged liability and duty are creatures of the statute or whether they are merely indicia of common law negligence. Loss suggests, however, that courts have not questioned the federal jurisdiction once they decided that there was an implied right of action. Loss, op. cit. supra at $1051-52$ and Supp. (1955) at 369, n. 375 . 
The implied liabilities under these statutes rest on two bases. One is the provision [s] . . . to the effect that every contract made in violation of the statute or any rule thereunder, as well as every contract whose performance will involve such a violation, shall be "void" ... . [This type of provision] can apply, of course, only where plaintiff and defendant are in privity of contract-or perhaps where the plaintiff can work out a third-party beneficiary relationship.

The other basis of the implied liabilities is the common-law tort doctrine of private action based on violation of a statute. There is much jurisprudential talk about the kind of statute which makes this doctrine operable. In general, so it is said, the interest invaded must be one which the enactment is intended to protect; where the enactment is designed exclusively to protect the interests of the state or the public as a whole, violation results in no civil liability. It is all a matter of "legislative intention." The courts have to be sure they are only "finding" and not "making" the law.

The implication of a private right of action under federal securities laws developed first and has flourished most under the Securities Exchange Act of 1934, in particular under section ro(b) and Rule X-roB-5 promulgated thereunder. ${ }^{52}$ The availability of a civil remedy under section ro(b) was first discussed in Kardon v. National Gypsum Co. ${ }^{53}$ In that case the court, relying on the Restatement of Torts, found disregard of a statutory command to be tortious. In the absence of a clear indication that Congress intended to withhold from injured parties the right to recover damages caused by the statutory violation, the court upheld the private right of action. Emphasizing the purpose of the statute, the Kardon court concluded that the mere omission of civil liability provisions was not sufficient to negate the common law implication of a private right of action.

The Kardon opinion also suggested that relief could be founded on section 29 (b) of the 1934 act, the statutory voiding provision which "almost necessarily implies a remedy in respect of it." Th4 This void contract theory of implied liability was more fully developed in

${ }^{52}$ See Annot., 37 A.L.R.2d 649 (1954), Civil Action by Private Person uthler $\S$ ro(b) of Securities Exchange Act of $x 934$; Note, 1961 DUKE L.J. 330. 4 STAN. L. REv. 308 (1952) argues that privity of contract is not required for a cause of action under $\S$ ro(b) and Rule X-1oB-5. Contra, Joseph v. Farnsworth Radio \& Tel. Corp., 99 F. Supp. 701 (S.D.N.Y. 1951), aff'd, 198 F.2d 883 (2d Cir. 1952).

${ }^{53} 69$ F. Supp. 512 (E.D. Pa. 1946), 73 F. Supp. 798, opinion amended, 83 F. Supp. 613 (1947). For discussion of the case, see Latty, The Aggrieved Butyer or Seller or Holder of Shares under the S.E.C. Statutes, 18 LAW \& CoNTEMP. Prob. 505 (1953).

$$
\text { 37 A.L.R.2d 649, 651 (1954). }
$$


Goldstein v. Groesbeck, ${ }^{55}$ a stockholders' derivative suit to recover moneys paid under a service contract that was illegal and void under the Public Utility Holding Company Act. The Court of Appeals for the Second Circuit, utilizing the void contract theory, held that the complaint was good against a motion to dismiss. ${ }^{5 B}$

In 1958, the District Court for the Southern District of New York considered a private action brought under section 7 of the Investment Company Act, which makes unlawful certain transactions by unregistered investment companies. Cogan $v$. Johnston ${ }^{57}$ was both a derivative and a representative action. The complaint charged the defendant directors with conspiracy to circumvent the I940 Act and "to freeze out the public stockholders by transactions in violation of the Act," with causing the company "to violate the Act for their own interests," and with "gross abuse of trust as corporate officers and directors." Jus Jurisdiction was based on section 44 of the act and also on section 36 , which authorizes the Commission to seek an injunction against gross abuse of trust by directors, officers, and other affiliates. Plaintiffs sought injunctive relief and also the appointment of a receiver to msure that the company complied with the I940 Act. In denying a motion to dismiss for lack of jurisdiction over the subject matter, the court indicated that individuals could bring private actions in federal courts to enforce liabilities and to enjoin violations under the act. Although the court approved implication of jurisdiction for private actions from section 36 , in this particular case such jurisdiction did not attach because

\footnotetext{
EE I42 F.2d 422 (2d Cir. I944).

${ }^{86}$ In discussing the Public Utility Holding Company Act, the court said:

"As we have seen the Act makes it unlawful for unregistered holding companies to enter 'directly or indirectly' into service or construction contracts .... . Violation being thus established, $\S_{2} 6(\mathrm{~b})$... . in express terms declares the contracts void. It should follow that the operating companies are entitled to a refund, for no other result can fulfill the expressed purpose of the Act of protecting subsidiaries from the overreachings of holding companies. Thus, the statutory declaration of the necesssity for control of holding companies ... states, inter alia, that the national public interest is adversely affected when subsidiary public utility companies are subjected to excessive charges for services. The three specific sanctions stated in the Act-injunction ..., criminal punishment ...., and the negative relief of ... declaring the contracts void-do not in terms place the defrauded operating company in statu quo; and $\S 26$ [the contract voiding provision] is incomplete, if not ineffective, unless it is considered to authorize recovery by operating companies .... [W] think a denial of a private right of action to those for whose ultimate protection the legislation is intended leaves legislation highly publicized as in the public interest in fact sadly wanting, and even delusive to that end." 142 F.2d at 426-27.

${ }^{67}$ I62 F. Supp. 907 (S.D.N.Y. 1958).

${ }^{68} \mathrm{Id}$. at 908 .
} 
the investment company involved was an unregistered company, and section 36 pertains only to registered companies.

In a more recent case, Taussig v. Wellington Fund, Inc., ${ }^{50}$ a district court approved private actions under section 36 of the act. This approval was actually dictum, since relief was granted on common-law grounds, but the court said: ${ }^{60}$

Violation of a federal statute may accord a private litigant a remedy by implication notwithstanding the absence of specific statutory authority conferring upon the injured the right to redress statutory wrongs, for the common law will supply a remedy where the statute is silent. . . .

The intention to create civil liability is presumed unless a contrary legislative intent is to be inferred from the whole purview of the Act ....

It is one thing to say that the three [SEC] statutes in question were drafted with the overall intent to protect the investing public but something quite different to conclude a competitor has no standing to prosecute a violation of these enactments.

Private rights of action in tort law are commonly implied from penal statutes. Accordingly, the district court in Bullock showed no hesitation in implying a right of action under section 37 , which deals with larceny and embezzlement from registered investment companies. But section 36 , the gross abuse of trust section, provides only an administrative remedy to terminate misconduct by officials of registered investment companies; it imposes no penal sanction at all. The Bullock court noted this absence of criminal sanction in the section, but relied on a pronouncement of the Supreme Court: ${ }^{61}$

\footnotetext{
${ }^{50}$ I87 F. Supp. 179 (D. Del. 1960).

${ }^{60}$ Id. at $217,219$.
}

This court takes an even broader view of implied rights of action than does $\S 286$ of the Restatement of Torts, quoted at note 51 supra. The court says (by way of dictum):

"In the present context, federal statutory remedies accorded by implication must be held to extend to persons other than the investing public in certain compelling instances. To begin with, in particular circumstances the investors' interest is peculiarly served by according remedial rights by implication to persons other than investors. The administrative agency exercising appropriate discretion may decide not to institute the required action to protect the injured litigants' interests. Further, there may be no remedy conferred by State law, or in the case of an enterprise engaged in multi-state activities, local relief may be entirely inadequate. The crux of the matter is, plaintiffs are not acting as private attorneys general, or as a special representative of the Commission. Plaintiffs are in Court in an attempt to vindicate the rights and protections which they claim are secured to [the investment company] by virtue of federal law." $I d$. at 219. (1930).

${ }^{21}$ Texas \& N.O. R.R. v. Brotherhood of Ry. and S.S. Clerks, 281 U.S. 548, 569 
The absence of a penalty is not controlling. The creation of a legal right by language suitable to that end does not require for its effectiveness the imposition of statutory penalties. Many rights are enforced for which no statutory penalties are provided.

Historically, the Investment Company Act was written only after an extensive study by the SEC had unveiled a multitude of abuses in management of investment companies, and then the industry itself cooperated with the Commission in drafting a bill. The various congressional reports ${ }^{62}$ on the investment company bills do not discuss implied private rights of action. The Brouk decision suggests, however, that the well-nigh unanimous support which the industry accorded the final bill would not have been forthcoming if Congress had envisioned such private rights of action. However, the legislative history is inconclusive on this point. ${ }^{63}$

In determining whether Congress meant to control or regulate or expand the common law duties of investment company directors and, in general, whether Congress intended to provide private remedies under the Investment Company Act, the Court of Appeals in Brouk utilized the maxim expressio unius est exclusio alterius. The court erroneously assumed that the act contains no express civil liability provision, ${ }^{64}$ and then applied this maxim on an inter-statutory basis to negate the plaintiffs' claim of implied civil liability. ${ }^{65}$ The expressio unius argument more frequently arises upon intra-statutory construction. However, it has been specifically rejected by the Second Circuit in a case under the Securities Exchange $A c^{66}$ and by the Supreme Court in a case under the Securities Act. ${ }^{67}$ The Supreme Court promulgated instead the doctrine that "courts will construe the details of an act in conformity with its dominating general purpose, will read text in the light of context and will interpret the text so far as the meaning of the words fairly permits so as to carry out in particular cases the generally expressed legislative policy.... ग68

${ }^{09}$ The congressional records are listed by the Bullock court at pp. $93,360-6 \mathrm{I}$ of CCH FED. SEC. L. REP. I 9I, Or 3.

${ }^{63}$ For discussion of the legislative history, see Jaretzki, The Investment Company Act of 1940,26 WASH. U.L.Q. 303 (1941); Greene, Fiduciary Standards of Conduct Under the Investment Company Act of r940, 28 GEO. WASH. L. REv. 266 (1959).

${ }^{84}$ See note 46 supra.

${ }^{05}$ Brouk v. Managed Funds, Inc., 286 F.2d 901, 912 (8th Cir. I96I).

${ }^{\circ 0}$ Baird v. Franklin, I4I F.2d 238 (2d Cir.), cert. denied, 323 U.S. 737 (1944).

${ }^{07}$ SEC v. Joiner Corp., 320 U.S. 344 (1953).

${ }^{68}$ Id. at $350-5 \mathrm{I}$. 
The Bullock court based its interpretation of the Investment Company Act on what it considered to be the dominating general purpose of the act: $:^{89}$

The 1940 Act, regulating in depth a particular industry, is much more comprehensive in thrust and scope than the 1934 Act. In certain major respects, the 1940 Act operates as a corporation law for investment companies. In sharp contrast, the 1934 Act (like the I933 Act) regulates one phase,一the purchase and sale of corporate securities. The distinction is between commodity regulation and industry regulation. The protective reach of the latter extends to the corporation as well as the stockholder and the public generally.

In light of the distinctive character of investment companies and their easy susceptibility to management abuses (e.g., looting of the companies by insiders' using means both crude and subtle), one of the primary objectives of the 1940 Act was the protection of investment companies as well as investors against the derelictions of investment companies' directors, investment advisers, other fiduciaries, and principal underwriters. To say that the 1940 Act was not intended in part to protect investment companies is to emasculate the statute.

Unlike prior federal securities legislation, the Investment Company Act sets forth its purpose elaborately; in section $I^{70}$ it declares:

the national public interest and the interest of investors are adversely affected ... when investment companies are organized, operated, managed, or their portfolio securities are selected, in the interest of directors, officers, investment advisers, depositors, or other affliated persons thereof in the interest of underwriters, brokers, or dealers . . . rather than in the interest of all classes of such companies' security holders; ... when investment companies are managed by irresponsible persons ....

Section I also includes a "congressionally promulgated canon" of construction:

It is declared that the policy and purposes of this chapter, in accordance with which the provisions of this chapter shall be interpreted, are to mitigate

${ }^{80}$ CCH FED. SEC. L. REP. T 91,01 3 at p. 93,373. The court further stated that "the 1940 Act, through numerous specific provisions, created an entire pattern of prescriptions and prohibitions with respect to the organization of investment companies, the composition of their boards of directors, voting rights, the terms and conditions of contracts eutered into by investment companies and their investment advisers and managers and principal underwriters. Manifestly, the overall policy, objectives and mechanism of the 1934 Act and the 1940 Act are widely different." Ibid.

${ }^{70}$ The First Circuit has alluded to this section of the act as codifying "the fiduciary obligations placed upon offcers and directors of investment companies." Aldred Inv. Trust v. SEC, 151 F.2d 254, 260 (1st Cir. 1945), cert. denied, 326 U.S. 795 (1946). 
and, so far as is feasible, to eliminate the conditions enumerated in this section which adversely affect the national interest of investors.

The Brouk and Bullock courts, after searching out congressional intention underlying the Investment Company Act, came to antithetical views. The superficial factual distinctions in the two cases ${ }^{71}$ do not adequately reconcile their diverse approaches to statutory construction. Inasmuch as the federal judiciary has traditionally taken a liberal view of its jurisdictional powers in securities regulation, the Bullock philosophy seems more likely to prevail. The implied right of action under the Investment Company Act, if recognized, will surely assume major importance in the regulation of investment companies.

\footnotetext{
${ }^{71}$ See note 34 supra.
} 